\title{
Biodegradation of phenolic components in wastewater by micro algae: a review
}

\author{
Muthanna Al-Dahhan ${ }^{l}$, Faris Al-Ani ${ }^{2}$ and Afaf Al-Saned ${ }^{2}$ * \\ ${ }^{1}$ Missouri University of Science and Technology, Rolla, MO 65409, USA \\ ${ }^{2}$ Building and Construction Engineering Department, University of Technology, Baghdad, Iraq
}

\begin{abstract}
The biodegradation of phenolic contaminant present in wastewater by micro algae has been investigated in the current research. The study focused on algae growth requirements and factors affecting algae growth in contaminated water leading to the best treatment. Different techniques used to functionalize microalgae in the treatment such as batch and continuous operation modes have been further investigated. Mechanisms for microalgae pollutants degradation and microalgae growth kinetics were also highlighted to present the required knowledge in phenol contaminant biodegradation field by microorganisms
\end{abstract}

\section{Introduction}

Among the most essential environmental issues, pollution of surface water has become a standout problem among the most imperative environmental issues. Two sorts of substantial and long-lasting pollution dangers can be perceived at the worldwide level. Organic contamination prompting by high organic content in aquatic ecosystems and eutrophication. Polluted water can affect water quality in a manner, of confining utilization of water, bodies for some reasons.

Organic pollution happens when huge amounts of organic compounds from numerous sources are discharged into running waters, lakes and seas. Organic pollutants are derived from farm water, industrial effluents, urban runoff and domestic sewage. Organic pollution could adversely influence the water quality in numerous ways.

one of the 129 specific significance chemicals is Phenol, which is considered toxic under the 1977 modifications to the Clean Water Act and for which the US Environmental Protection Agency (EPA) has issued water quality standards [23]. Phenol is an aromatic hydrocarbon containing a hydroxyl group $(\mathrm{OH})$ tied to the benzene ring. It is a basic structural unit for a diversity of artificial organic compounds. As an organic substance, phenol is soluble in most organic solvents and it is slightly soluble in water at room temperature [1]. Phenols are divided either as natural or synthetic nonaromatic compounds in different environmental sites as major pollutants. Due to the aromatic structure of phenol, it is renitent to biodegradation naturally and phenolic compounds have been reported to have high stability because of the difficulty of cleaving the benzene ring.
Effective treatment methods are available for the removal of hydrocarbons and phenols such as activated carbon adsorption, ion exchange, liquid-liquid extraction, and chemical oxidation; however, they often suffer from dangerous drawbacks such as high cost. In addition, most of these techniques do not degrade organic compounds, but rather transfer it to another phase, which lead to the realization of dangerous byproducts (secondary pollution). On the other hand, biodegradation is considered a more environmental friendly and cost-effective alternative. So, biological treatment has been an increasingly important process in pollution control). However, a lot of microorganisms can tolerate phenol and using it as a carbon and energy source. The biological degradation is done through benzene ring cleavage using the enzyme presents in the microorganism [14].

\section{Biological treatment method}

The biological treatments are globally preferred when they are compared to physiochemical methods due to the possibility of complete mineralization of the toxic compounds from aqueous solutions while producing innocuous end products, maintaining concentrations of pollutants below the toxic limit, cost competitive, there are no chemicals involved and no secondary problems (toxic by-products) in the effluent. Relying on the microbial ability of growing in specific conditions, organic material can be degraded anaerobically or aerobically. Though aerobic and anaerobic, microorganisms can degrade phenol and other organic compounds; commonly aerobic processes are preferred. For degrading toxic compounds, aerobic microorganisms are more effective because they grow faster and commonly transform organic compounds to inorganic

Corresponding author: jadaan 64@,yahoo.com 
compounds $\left(\mathrm{H}_{2} \mathrm{O}, \mathrm{CO}_{2}\right)$. Aerobic processes are also preferred because of the low cost related with this option large number of microorganisms including bacteria, fungi, and algae are capable of degrading phenol [25].

\section{Microalgae}

Microalgae are microscopic photosynthetic microorganisms. They are a type of eukaryotic cells and they contain similar organelles such as chloroplasts, nucleus, etc. Microalgae are generally, more efficient than land plants in utilizing sun light, $\mathrm{CO} 2$, water and other nutrients which are translated to higher biomass yields and higher growth rates. They can crown and grow in a different aquatic environment. Microalgae can be crowned without the use of fertilizers and pesticides which results in less waste and pollution.

Algae are included in the plant kingdom and are distinguished from other Chlorophyllous plants on the basis of sexual reproduction. There are seven divisions of algae, divisions that include the larger visible algae are: Cyanophyta (blue-green algae), Chlorophyta (green algae), Rhodphyta (red algae) and Phaeophyta (brown algae). These divisions are subdivided into orders, which are subsequently divided into families and then into genus and species. The main differences between these types of algae are in cell wall, where sorption takes place [33].

\section{Algae growth requirements}

Microalgae have a particular set of requirements for growth identical to that of other photosynthetic plants. Basic inputs for microalgae growth include water, sunlight, nutrients and an acceptable range of environmental conditions particular to the algal species. Environmental conditions like temperature, $\mathrm{pH}$, salinity, and dissolved gases may influence the growth characteristics of microalgae. Growth inputs have an optimum range of supply, and providing the optimum growth conditions produce the largest algal population. Generally speaking, larger algal populations lead to greater amounts of algal biomass [9].

Successful treatments of wastewater with microalgae require a good growth, and understanding of the factors that influence growth is therefore essential. The growth rate of algae and cyanobacteria is affected by biological, chemical and physical factors.

\subsection{Light "photo" requirements}

Microalgae require a dark period as well as a light period for growing which is known as a photoperiod. The dark period allows the algae to respire while the light period permits photosynthesis to occur. The photosynthesis reaction is shown below as Equation 1 [10].

$$
6 \mathrm{CO}_{2}+6 \mathrm{H}_{2} \mathrm{O}+\text { light } \leftrightarrow \mathrm{C}_{6} \mathrm{H}_{12} \mathrm{O}_{6}+6 \mathrm{O}_{2}
$$

Chloroplasts absorb light energy, and in the presence of $\mathrm{CO}_{2}$ and water transform the captured energy into potential chemical energy In this way photosynthesis converts light energy along with $\mathrm{CO}_{2}$ and water into chemical energy in the form of carbohydrates and releasing oxygen in the process. Through the dark phase, respiration follows the same equation proceeding in the opposite direction.

The mathematical model showed that degradation of phenolic compounds is improved by increasing the light intensity in a broad range of light intensities; which is mainly attributable to increases in photosynthetic oxygen production. Both biodegradation rate and microalgae growth can be improved under increased light intensities, by addition of inorganic carbon sources such as $\mathrm{CO} 2$ and sodium bicarbonate (NaHCO3) [26].

\subsection{Nutrient requirements}

Carbon is an essential nutrient for the growth of microalgae. $\mathrm{CO} 2$ is a main ingredient driving photosynthesis and is the primary GHG to be sequestered.

The carbonic acid $(\mathrm{H} 2 \mathrm{CO} 3)$ results from injection $\mathrm{CO} 2$ into water, therefore lowering the water $\mathrm{pH}$. The following set of equilibrium equations clarify how $\mathrm{H}_{2} \mathrm{CO}_{3}$ behaves in an aqueous solution and recognize the carbonic species that are consumed by microalgae according to the $\mathrm{pH}[42]$.

$$
\begin{gathered}
\mathrm{CO}_{2}(\text { gas })+\mathrm{H}_{2} \mathrm{O}(\mathrm{aq}) \rightarrow \mathrm{H}_{2} \mathrm{CO}_{3}(\mathrm{aq}) \\
\mathrm{H}_{2} \mathrm{CO}_{3} \leftrightarrow \mathrm{H}^{+}+\mathrm{HCO}_{3}^{-} \\
\mathrm{HCO}_{3}^{-} \leftrightarrow \mathrm{H}^{+}+\mathrm{CO}_{3}^{2-}
\end{gathered}
$$

However, since the ambient atmospheric concentration $(0.033 \%)$ is far below optimum for algal growth, supplying of extra carbon dioxide may be necessary. This can be achieved by providing the cultures with air enriched with 1 to $5 \% \mathrm{CO}_{2}$ [20].

Besides carbon, the second basic nutrients are nitrogen, phosphorous, and potassium. The essential macro nutrients required for all plants are potassium (K), phosphorous (P) and Nitrogen (N). Usually plant fertilizers are classified by their N-P-K ratios.

Different micro nutrients such as calcium $(\mathrm{Ca})$, iron (I), magnesium $(\mathrm{Mg})$, sulfur $(\mathrm{S})$, zinc $(\mathrm{Zn})$, and different trace elements are also basic for a full satisfaction to the nutrient requirements of microalgae. Because microalgae are suspended in water, there is a great availability of nutrient, and thus maintaining enough nutrient levels is fundamental for optimum algal growth. Atmospheric carbon dioxide may be provided to algal cultures by means of aeration [28].

\subsection{Environmental requirements}

Environmental conditions play an important role in governing the microalgae growth. Environmental parameters such as salinity, $\mathrm{pH}$, temperature and dissolved oxygen ultimately have an impact on the success of algal cultivation. The microalgae population is around of 100,000 recognized species. Therefore, the 
ideal environmental conditions are particular to the different algal species [11].

\section{Microalgae for wastewater treatment}

The biological treatment of wastewaters is based on the capacity of naturally occurring microorganisms to degrade pollutants presented in the aquatic environment. Most studies on biodegradation to date have focused on bacteria or fungal mediated processes. The idea of using microalgae and/or cyanobacteria in decontamination processes, such as in the treatment of domestic wastewater was initially proposed in the late 1950's. Since that period, there have been number of reports on microalgae use in biological treatment strategies.

Their uses in such applications have the main advantage of being able to generate microbial biomass from a cheap and most abundant energy source (sunlight). Another benefit is that additional pollution is not generated when the biomass is harvested and efficient recycling of nutrients is possible [29].

Photosynthetic oxygen-evolving cyanobacteria are ideal for the treatment of some effluents containing xenobiotic since unlike heterotrophic organisms; they can undertake biodegradation simultaneously with oxygenation Some marine cyanobacteria have been successfully used in the treatment of solid wastes and wastewaters containing pesticide, phenols, aromatic hydrocarbons, textile dyes, removing uranium from mining wastewater and detergents. This is primarily due to their capacity to metabolize these compounds as nitrogen, phosphorus, carbon and sulfur sources. They have also been used to reduce the content of nitrogen, ammonia and phosphorous in sewage and various agricultural wastes. Microalgae Scenedesmus Chlorella, cyanobacteria Phormidium and Oscillatoria are the most frequently used genera in wastewater treatment systems mediated by microalgae and/or cyanobacteria. The use of these microorganisms led to a progressive reduction of chemical oxygen demand (COD) and biological oxygen demand (BOD), to values below the disposal limits [36].

Microalgae have also been successfully employed in the reduction of heavy metal content in industrial wastewaters, both in batch or in continuous systems. Additionally, the acidic nature of some industrial wastewater can be buffered by algal growth. The growth of algae in wastewater can balance the acidity which can help reducing harmful degradation of waste infrastructure [22].

\section{Degradation of phenolic compounds by microalgae}

Till now, researches on phenol biodegradation have almost exclusively concentrated on the use of bacteria and fungi. However, these bacteria and fungi may further aggravate the pollution problem because of anaerobic degradation of the aromatic amino acids exist in the wastewater that may further result in release of phenol and cresol Even in low concentration, phenolic compounds are so toxic to organisms. However, some microorganisms are capable of utilizing them as carbon and energy source [34]

Many phenols show acute toxicity to algae, both cyanobacteria and eukaryotic microalgae are able to biotransforming aromatic combinations, including phenols [36].

Semple et al. [36] examined the catabolic versatility of the microalgae Ochromonasdanica (CCAP 933/2B) to degrade mixtures of phenols. It was observed that after growth of algae, all phenol had disappeared from a phenolic mixture in the incubation media in 2 hours.

Shashirekha et al. [38] reported inhibitory effects of phenol on the growth of phormidium photosynthetic conditions up to $100 \mathrm{mg} / \mathrm{L}$.

Ishihara and Nakajima [19] reported the removal of bis-phenol from a medium spiked with 40 um of bisphenol by two marine microalga strains of nannochloropsis sp. And chlorella gracilis up to a level of $34 \%$ and $53 \%$ respectively over a period of 6 days under light.

. Pinto et al. [30] reported the removal of more than $70 \%$ of phenol by two green microalgae, ankistrodesmusbraunii and scenedesmusquadricauda from olive-oil mill wastewaters within 5 days of treatment. This was similar to those obtained with fungi and bacteria.

$\mathrm{D}$ and $\mathrm{N}$ [12] tested the capability of the microalgae Chlamydomonasreinhardtii, Chlorella vulgaris Beyerinck, Scenedesmusquadricauda and blue green microalgae Anabaena ambigua, Nostocmuscorum, Oscillatoria animals and Oscillatoria sancta to use phenol as carbon source on agar salt medium. The study demonstrated better growth of algae and they were capable of degrading all phenol levels in culture medium. However,

\section{Culturing techniques}

Generally, there are two systems for mass photosynthetic microorganism production, either open or enclosed system. The open systems, i.e., raceway ponds and lakes, are usually illuminated naturally (outdoors) and open to the environment. They are cost-effective but intrinsically hard to control. Hence, they are usually used to grow resistant strains, such as Spirulina platens and Dunaliela Salina. Those strains can resist hard environmental conditions (such as high $\mathrm{pH}$ for Spirulina and high salinity) that prevent contaminations by other strains.

The enclosed systems, usually called photo bioreactors (PBR) have numerous possible photo bioreactor (PBR) configurations (e.g., tubular, panel, internally illuminated, airlift bubble column reactors) as shown in Figure (1). 


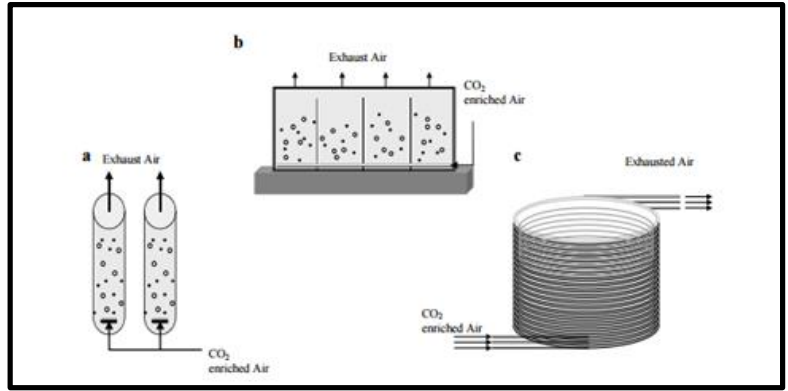

Fig. 1. Schematic presentation of a vertical column reactor (a), a flat plate reactor (b), and tubular photo bioreactor arranged in spiral [27].

Table 1 shows a summary of researches performed in different PBR configurations using various microorganisms.

Table 1. Summary, of Continuous and, Semi-Continous Cultivation of Microalgae

\begin{tabular}{|c|c|c|c|c|c|c|}
\hline Author & [15] & [39] & [41] & {$[16]$} & {$[18]$} & [43] \\
\hline $\begin{array}{l}\text { Specie } \\
\mathrm{s}\end{array}$ & $\begin{array}{l}\text { Chorell } \\
\text { a } \\
\text { vulgari } \\
\text { s }\end{array}$ & $\begin{array}{l}\text { Thermos } \\
\text { ynechoco } \\
\text { ccussp }\end{array}$ & $\begin{array}{l}\text { Chlorella } \\
\text { minutissi } \\
\text { ma, } \\
\text { D.tertiole } \\
\text { cta }\end{array}$ & $\begin{array}{l}\text { Scened } \\
\text { e- } \\
\text { smus } \\
\text { obliqu } \\
\text { us } \\
\end{array}$ & $\begin{array}{l}\text { Cyan } \\
\text { o- } \\
\text { bium } \\
\text { sp. }\end{array}$ & $\begin{array}{l}\text { Chlorella } \\
\text { vulgaris }\end{array}$ \\
\hline Type & & $\begin{array}{l}\text { Cyanoba } \\
\text { cte-rium }\end{array}$ & $\begin{array}{l}\text { freshwate } \\
r\end{array}$ & $\begin{array}{l}\text { Fresh } \\
\text { water }\end{array}$ & & $\begin{array}{l}\text { Fresh } \\
\text { Water }\end{array}$ \\
\hline Media & $\begin{array}{l}\text { Artifici } \\
\text { al } \\
\text { Waste } \\
\text { Water }\end{array}$ & $\begin{array}{l}\text { Fitzgeral } \\
\text { d media }\end{array}$ & $\begin{array}{r}\text { Modified } \\
\text { Bold 3N }\end{array}$ & $\begin{array}{l}\text { Jawors } \\
\text { ki }\end{array}$ & $\begin{array}{l}\text { BG1 } \\
1\end{array}$ & $\begin{array}{l}\text { Diluted } \\
\text { Manure }\end{array}$ \\
\hline $\begin{array}{l}\text { Media } \\
\text { Supple } \\
\text { ment }\end{array}$ & $\begin{array}{l}\text { Glucos } \\
\text { e } \\
\text { NH4C } \\
\text { L }\end{array}$ & $\begin{array}{l}15 \% \mathrm{CO} 2 \\
\text { absored } \\
\text { by } \mathrm{NaOH} \\
\text { solution }\end{array}$ & $\begin{array}{l}\text { 3xReg.N } \\
\text { aNO3 }\end{array}$ & & $\begin{array}{l}0.4- \\
1.6 \mathrm{~g} / \\
1 \\
\mathrm{NaH} \\
\mathrm{CO} 3\end{array}$ & \\
\hline $\begin{array}{l}\text { Worki } \\
\text { ng } \\
\text { Vol.(L } \\
\text { ) }\end{array}$ & 2 & 1 & $3-6$ & 500 & 1.8 & 1 \\
\hline $\begin{array}{l}\text { PBR } \\
\text { Design }\end{array}$ & $\begin{array}{l}\text { Tubula } \\
\mathrm{r}\end{array}$ & Tubular & CSTR & $\begin{array}{l}\text { Fence+ } \\
\text { Tank }\end{array}$ & $\begin{array}{l}\text { Tubu } \\
\text { lar }\end{array}$ & $\begin{array}{c}\mathrm{L} \\
\text { flasks }\end{array}$ \\
\hline $\begin{array}{l}\text { Light } \\
\text { source }\end{array}$ & ------ & ------ & $\begin{array}{l}\text { Circular } \\
\text { LED }\end{array}$ & $\begin{array}{l}\text { Sunlig } \\
\text { ht }\end{array}$ & ----- & $\begin{array}{l}\text { Fluoresce } \\
\text { nt lamp }\end{array}$ \\
\hline $\begin{array}{l}\text { Tem. }\left({ }^{\circ}\right. \\
\text { C) }\end{array}$ & 30 & & 25 & & 30 & $25 \pm 2$ \\
\hline$\% \mathrm{CO} 2$ & & & 4 & $\begin{array}{l}3 \\
\text { (contro } \\
1 \\
\mathrm{pH})\end{array}$ & & $\begin{array}{l}2 \text { (for } \mathrm{pH} \\
\text { control) }\end{array}$ \\
\hline $\begin{array}{l}\text { Growt } \\
\text { h rate } \\
\text { (d-1) }\end{array}$ & & & & $\begin{array}{l}0.03- \\
0.23\end{array}$ & & \\
\hline $\begin{array}{l}\text { Dilutio } \\
\text { n rate }\end{array}$ & $0.5-1.5$ & $1.4 \mathrm{~d}-1$ & $\begin{array}{l}0.076- \\
0.64 d-1\end{array}$ & $\begin{array}{l}\text { Not } \\
\text { specifi } \\
\text { ed }\end{array}$ & $\begin{array}{l}\text { Not } \\
\text { const } \\
\text { ant }\end{array}$ & $\begin{array}{l}0.05- \\
0.3 \mathrm{~d}-1\end{array}$ \\
\hline $\mathrm{pH}$ & $8-10$ & $10-11.5$ & $\begin{array}{l}7.8 \\
\text { (initial) }\end{array}$ & $7.0 \pm 0.2$ & & \\
\hline
\end{tabular}

Table (2) shows various tubular photo bioreactor characteristics, focusing on the algal species employed, the main parameters useful to the biomass growth (temperature and $\mathrm{pH}$ ), the adopted mechanism of circulation, the methods of light supply and the maximum illumination flux provided, the system of $\mathrm{CO} 2$ supply and the materials employed in the construction of the re actors. [42].
Photobioreactor can be either illuminated naturally or synthetically (indoors) and permit axenic cultures under full control. These enclosed systems, therefore, are suitable for growing strains for high value products, as these strains usually need protection from the exterior environment and should be maintained at suitable temperature, $\mathrm{pH}$ value, salinity, etc [17].

Among all sorts of photo bioreactors studied, airlift column reactors have emerged as one of the most promising photo bioreactors for their excellent mixing intensity. These reactors have been widely used in the chemical, biochemical fermentation and biological wastewater treatment industries where high mass transfer and good mixing are required. These reactors possess numerous advantages that are especially appropriate for mass microalgae/cyanobacteria culture, such as simple construction, long liquid phase residence time, and low shear stress while maintaining high turbulence intensity. Therefore, exploring the possibility of applying airlift column reactors in mass autotrophic microorganism production and advancing the understanding. In air lift column, photo bioreactors, air (or any other gas) is spargered into the column from the riser leading to a continuous cyclical recirculation. of liquid and solid (if any, e.g., cells) phases in the reactor. The advantages of the airlift reactor are [31]:

1- Stable.

2- Little power consumption.

3- High mass transfer.

4- High heat transfer characteristics.

5- Good solid suspending.

6- Homogeneous shear.

7- Easy to control.

8- Operational flexibility.

9- Rapid mixing.

The homogeneity inside the reactor can further provide a consistent metabolic state to the cells and the light usage efficiency is high. Furthermore, the scalability of the airlift reactors is better than the other kinds of reactor mentioned above [21].

Kanhaiya.et al. [24] have examined the suitable design of photo bioreactors for $\mathrm{CO}_{2}$ sequestration addressing global warming using green algae and cyanobacteria. The Biological fixation of $\mathrm{CO}_{2}$ culture density can produce renewable energy carriers such as carbon free energy hydrogen, bioethanol, biodiesel and other valuable biomolecules. The results showed that Airlift reactor seems the most promising for the $\mathrm{CO}_{2}$ sequestration.

A pilot plant designed by Sudarsan et al [40] to study the removal of ammonia Cal nitrogen by a biological system. The nitrification process was carried out in a sequential batch reactor and removal of nitrate from the system generated during the oxidation of ammonia Cal nitrogen was carried out in a photo bioreactor using algae. Results showed that $95 \%$ ammonia Cal nitrogen removal was done and $98 \%$ nitrate removal was done also by using algal photo bioreactor.

The cultivation of two algal strains; Chlorella vulgaris and Tetraselmis sp. in lab scale air lift photo bio reactors to estimate the feasibility of using flue gas as a carbon source for microalgae growth was conducted by Bryan 
[6]. The study demonstrated that the both microalgae species were capable of growing under flue gas dosing. And they are able to fixate $\mathrm{CO}_{2}$ from coal-fired flue gas. Deviram, et al. [13], developed a novel alternate method for wastewater treatment by using a special constructed column treatment plant. Algal species like Ulva sp, Cladophorasp and Chlorella sp used for the treatment of waste water. the treatment method were done in three stages, free cell manner, batch and continuous flow, continuous flow process with using chlorella sp showed better results, the percentage of COD and BOD removal were $52.1 \%$ and $50.8 \%$ respectively.

Rothemal [35] investigated the probability of coupling a conventional wastewater treatment system with an algal photo bio reactor to remove of phosphate and nitrate from wastewater and production of renewable resource was tested. The study showed whole nutrients were removed.

Amer [3] investigated the growth of Scenedesmus algae, cultivated in a split-column airlift bioreactor under three various light intensities and two values of superficial gas velocities. The obtained results indicate that the growth rate and chlorophyll content of the Scenedesmus algae directly proportional to light intensity and superficial gas velocity.

\section{Microalgae growth kinetics}

In order to estimate growth rates, a series of measurements at various times that allow the calculation of the rate of change in biomass concentration should be available. Cell number must be counted either through a direct method, as through light microscopy with a hemacytometer, or indirectly through biomass concentration as dry weight or optical density, as long as this measurement correlates linearly with the number of cells [2].

In a usual homogenous, batch regime (in a closed system), microalgae will pass through the following. growth phases as illustrated in Figure 2.

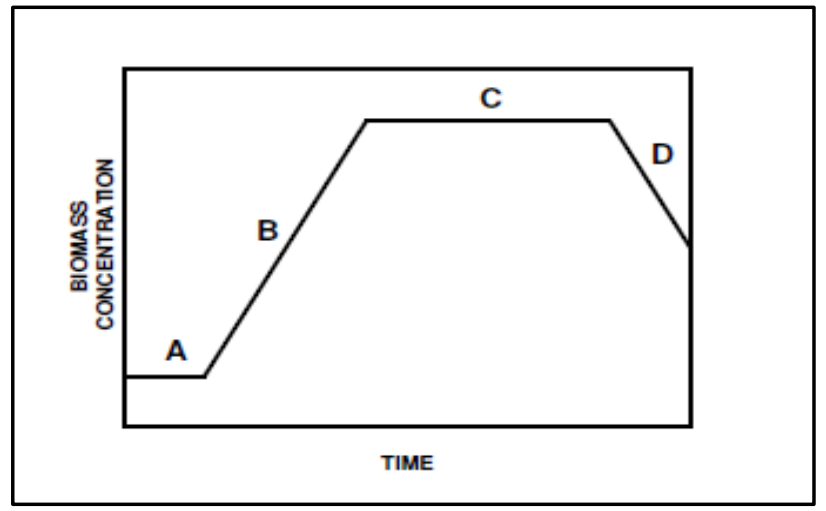

Fig. 2. Microalgae batch growth profile [2].
A. Adaptation (lag phase).
B. Exponential growth phase (log phase).
C. Stationary phase.
D. Logarithmic death phase.

The specific stages illustrated in Figure 2 are not always defined in a good manner. Their incline or length may differ according to the situations of culture. For the period of (phase A), the adaptation of microalgae cells to the new environments will accrue. When lag phase end, the cells are well adapted and then begin to increase rapidly, now this is the exponential phase (phase B), where the number of the living cells doubles in a regular tone with time in this phase [5].

Equations (5) and (6) describe cell growth:

$$
\begin{array}{ccc}
\frac{d n}{d t}=\mu n & \text { or } & \frac{1}{n} \frac{d n}{d t}=\mu \\
n=n_{0} \quad \text { or } & t=t_{0}
\end{array}
$$

Where $\mathrm{n}$ and $n_{0}$ are the concentrations of cells at various times $t$ and $t_{0}$, where:

$\mu$ is the specific growth rates and $t_{0}$ is referred as the initial time.

The following relation cab be generated from the integrated form of equation (5):

$$
\begin{gathered}
\ln \frac{n}{n_{o}}=\mu\left(t-t_{o}\right) \quad \text { or } \\
\mu=\frac{\boldsymbol{l n}^{n} / \boldsymbol{n}_{o}}{\boldsymbol{t}-\boldsymbol{t}_{\boldsymbol{o}}}
\end{gathered}
$$

From equation (7) it can deduce that the time required for cell population to double $\left(t_{d}\right)$ is given by:

$$
t_{d}=\frac{\ln ^{2}}{\mu}
$$

The state of the cell population can be characterized during the exponential phase using $\mu$ or $\mathrm{t}_{\mathrm{d}}$.

Media of fresh nutrients In open systems was supplementary in at the same ratio that medium is thoughtful from the culture; this saves the constant level of both growth parameters and cell concentration. Mass balance is applicable to any component of the System:

$$
\begin{gathered}
\text { rate of addition to system }- \text { rate of removal from } \\
\text { system }+ \\
\text { rate of production within system }=0
\end{gathered}
$$

The above can, be reformulated as:

$$
f x_{o}-f x+V r_{x}=0
$$

Where;

$f=$ volumetric. flow rate.

,$x_{0}=$ the concentration of biomass or cell in the feed stream.

$x=$ the cell concentrations in the system.

$\mathrm{V}=$ the cultures volume.

$r_{x}=$ the rate of cells formation.

If it is supposed that the growth rates is much higher than cell death rate and cell death is, neglected, if $\mu$ denotes the specific growth rate $\left(r_{x} / x\right)$, then it, can be substituted in equation (10) to obtain the following [7]:

$$
D x_{o}=(D-\mu) x
$$


The ratio of the volumetric, flow rate, at which fresh medium is added to the culture, is referred to as the dilution rate $D$, so that:

$$
D=f / V
$$

$D=$ dilution rate $\left(\right.$ time $\left.^{-1}\right)$

$f=$ flow rate

$V=$ reactor volume

It could be seen that, the dilution rates were inverse of residence time. Thus, increase the dilution rate increases the flow rate, and inversely decreases the residence time.

equation (13) and (14) are satisfied represented the the steady state of the system when the concentration of algae cell remain constant in the system [6].

$$
\begin{gathered}
\frac{d x}{d t}=0 \\
\mu=D
\end{gathered}
$$

When $D>\mu$ the nutrients are flowing through the reactor faster than the algae can divided in other, words. The organisms are being washed out of the reactors and only those cells attached, to a surface will stay and the cells cannot, grow fast enough to reach steady-state, washout will occur. as shown in figure (3).

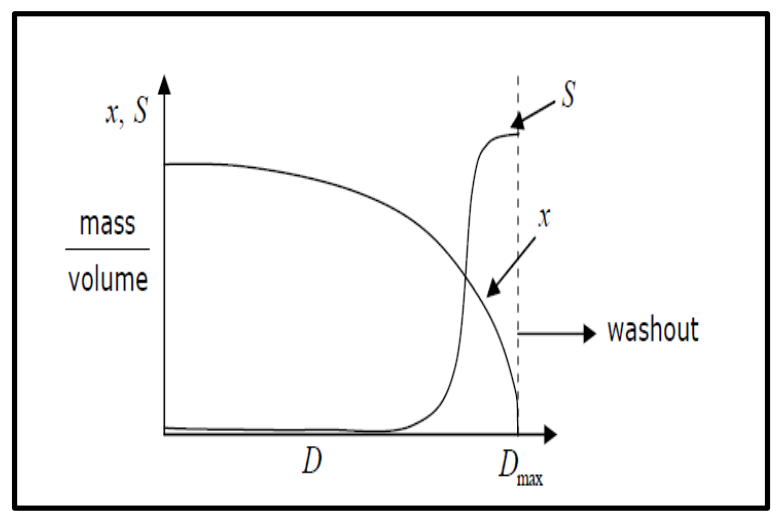

Fig. 3. Biomass / volume versus dilution rate beyond the maximum dilution rate, washout occurs. satisfied [6].

\section{Mechanisms for microalgae degradation of pollutants}

Microalgae and cyanobacteria are able to rapid uptake of nutrients and $\mathrm{CO}_{2}$ and possess quicker cell growth. They have been studied for their capability of degrading wide ranges of organic chemicals including pesticides. In the case, of some microalgae, the presence of molecular oxygen is indispensable. to initiates the enzymatic attacked on the aromatic ring and biodegradation of phenols only occurred under aerobic conditions. A typical pathway for metabolizing phenol is to hydroxylate the rings to form catechol that can be degraded through ortho or meta oxidationtion [36]. The reaction will be additional explained in "Enzymatic aspects. of the degradation processes by microalgae and, cyanobacteria and illustrated in the Figure (4).

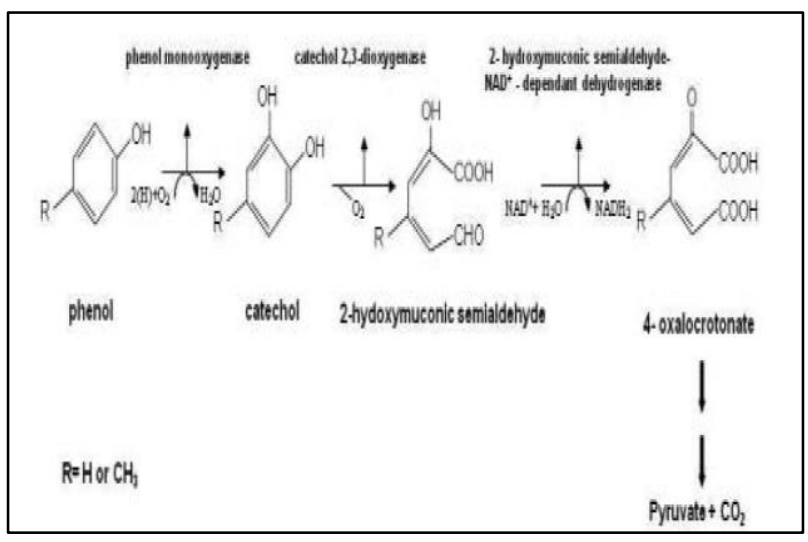

Fig. 4. Phenol biodegradation by meta cleavage pathway, described in the microalgae Ochromonasdanica [36].

\section{Conclusions}

In the current study, biodegradation of phenolic contaminate presented in wastewater by microalgae had been examined. The significant impact of microalgae in treating contaminated wastewater had been shown exploring the dominant factors that affected the biomass growth. Culturing techniques were further investigated to show the present development in such field. Different reactors set up like air left reactor were investigated to highlight the progress and benefits of culturing process under specific conditions. It had been noticed that studying microorganism kinetics and mechanisms possesses a great benefit in understanding the whole process leading to more development in the current field.

\section{References}

1. Agarry, S. E., Durojaiye, A. O., Yusuf, R. O., and Aremu, M. O. International Journal of Environment and Pollution, Vol.32, Pages:3-11. (2008)

2. Andersen R. AAlgal culturing techniques. 1st Edition Elsevier/Academic Press, Burlington, Mass. pp. 578. (2005).

3. Amer D. ZmatAlbdiri, Al-Qadisiyah" Journal For Engineering Sciences; Vol. 8, 410-421 (2015).

4. Bailey, J.E. and D.F. Ollis. Biochemical engineering fundamentals. McGraw-Hill, Montreal (1977).

5. Becker, E.W. Microalgae Biotechnology and Microbiology. Cambridge University Press, New York. (1994).

6. Bryan Daniel Brooker, Investigation of microalgae growth kinetics using coal-fired flue gas as a carbon. A Thesis Presented to The Faculty of California Polytechnic State University, San Luis 
Obispo. In Partial Fulfillment of the Requirements for the Degree Master of Science in Engineering, Specialization in Bioengineering. (2011).

7. Bailey, J.E. and D.F. Ollis. Biochemical engineering fundamentals. McGraw-Hill, Montreal. ,(1977).

8. Becker, E.W., Microalgae Biotechnology and Microbiology, Cambridge University Press, New York. (1994).

9. Chisit . Y and Moo.Young. M. Jchm Tech Biotech, Vol.42, 211-219 (1988).

10. Carvalho, P. A., Silva, O. S., Baptista, M. Jo., Malcata, F. X; Vol.89, 1275 -1288 (2011).

11. D. Samanthakamani and N. Thangaraju. Ind. J. Sci. Res. and Tech. Vol. 3, 9-12 (2015).

12. Deviram GVNS, Pradeep K. V and R GyanaPrasuna.European Journal of Experimental Biology; Vol. 1, 216-222 (2011).

13. El-Naas, M., Al-Zuhair, S., and Makhlouf, S., Journal of Industrial and Engineering Chemistry; Vol.16, 267-272 (2010).

14. Feng, Y., C. Li and D. Zhang, Bioresour. Technol. Vol.102, 101-105 (2011).

15. Hulatt, C.J. and D.N. Thomas, "Energy efficiency of an outdoor microalga lphotobioreactor sited at midtemperate latitude," Bioresour. Technol; Vol.102, 6687-6695 (2011).

16. Huang, G.H., Chen, F., Wei, D., Zhang, X.W., Chen, G., Appl. Energy; Vol.87,38-46(2010).

17. Henrard, A.A., M.G. de Morais and J.A.V. Costa,. Technol;Vol. 102, 4897-4900 (2011).

18. Ishihara. K, and Nakajima. N. J. Mo Catal BEnzym; Vol. 23, 411-417(2003).

19. Juang, R. S., and Tsai, S. Y. Biochemist Eng. J.; Vol.31, 133-140(2006).

20. Janssen, M., Tramper, J., Mur, L.R., Wijffels, R.H., Biotechnology. Boeing; Vol.81,193-210 (2003).

21. Kalin M., Wheeler W.N., Meinrath G., J. Environ. Radioactivity; Vol.78, 151- 177 (2005).

22. Kumar, A., Kumar, S., and Kumar, S. Biodegradation kinetics of phenol and catechol using Pseudomonas putrid. MTCC 1194 Biochemist Eng. J; Vol.22, 151-159(2005).

23. Kanhaiya Kumar a, Chitralekha Nag Dasgupta a, Bikram Nayak a, Peter Lindblad b, and Debabrata Das Bio resource Technology; Vol.102 ,4945-4953. Elsevier Ltd (2011).

24. Lika, K., Papadakis, I. A. J. Sea Res. Vol.62, 135146 (2009).

25. Lam, M.K. and K.T. Lee, "Potential of using organic fertilizer to cultivate Chlorella vulgaris for biodiesel production", Appl. Energy; Vol.94, 303308(2012).

26. Lee, J.S., Lee, J.P., Biotechnology Bioprocess E. Vol.8, 354-259 (2003).

27. Luo Hu-Ping, Muthanna H. Al-Dahhan, Biotechnology and Bioengineering; Vol. 85, (2004).

28. Pérez-Garcia, O.; Escalante, F.M.E.; de-Bashan, L.E.; and Bashan, Y. Water Res; Vol.45, 11-36. (2011).

29. Pinto, G.; Pollio, A.; Previtera, L.; Stanzione, M. and Temussi, F.Journal of Biotechnology; Vol.25, 1657-1659 (2003).
30. Petersen E. and Margaritis A. Crit. Rev. Biotechnol., Vol.21(4), 233-294 (2001).

31. Ruiz-Ordaz, N., Ruiz-Lagunez, J. C., Casta ̃n'onGonz'alez, J. H., Hern'andez- Manzano, E., Cristiani-Urbina, E., and Gal'nndez-Mayer, J. Rev. Latino am. Microbial; Vol.43, 19-25 (2001).

32. Romera, E., Gonzalez, F., Ballester, A., Blazquez, M.J., Crit. Rev. Biotechnology; Vol.26, 223235(2006).

33. Radwan, R.H. Al-Hasan, H.M. Mahmoud and M. EliyasJournal of applied miocrobiology; Vol.103 (2007).

34. Rothermel, Monica Christine, Coupling the Wastewater Treatment Process With An Algal Photo bioreactor For Nutrient Removal And Renewable Resource Production, Master's Thesis, University of Pittsburgh (2011).

35. Semple, K. T., \& Cain, R. B. Applied and Environmental Microbiology; Vol.62, 1265-1273 (1996).

36. Semple, K.T.; Cpain, RB.; FEMS Microbial Lett. Vol.170, Pages: 291-300 (1999).

37. ShashirekhaS,Uma L. Subramanian G. J. Ind Microbiol Biotechnol ;Vol.19 pages:130-133 (1997).

38. Su, C.M., H.T. Hsueh, H.H. Chen and H. Chu, Chemosphere. Vol.88, 706-711 (2012).

39. Sudarsan.J.S1, Renganathan.K2, and Ann Christy. international journal of environmental sciences; Vol.2, No. 1 (2011).

40. Tang, H., M. Chen, K.Y. Simon Ng and S.O. Salley. Biotechnol. Bioeng j. (2012).

41. Van Langenhove H, Kumar A, Ergas S, Yuan X, Sahu A, Zhang Q. [Internet]. 1st ed (2014).

42. Ugwu, C.U., Aoyagi, H., Uchiyama, H. Bio resource Technology; Vol.99(10) p. 4021-8. (2008).

43. Wang L, Min M, Li Y., and Chen P., Chen Y. Cultivation of green algae chlorella $\mathrm{sp}$. in different wastewaters from municipal wastewater treatment plant. Appl Biochemist; Vol.162, 1174-1186 (2010). 
Table 2. Different tubular photobioreactor systems

\begin{tabular}{|c|c|c|c|c|c|c|c|}
\hline 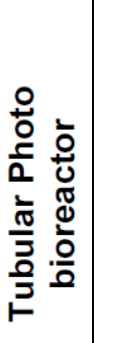 & 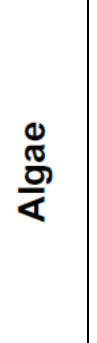 & 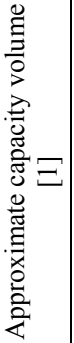 & v & $\frac{1}{2}$ & 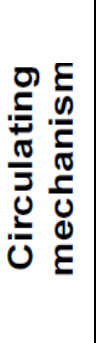 & 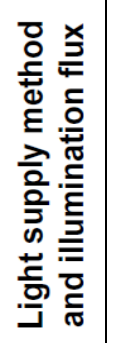 & $\begin{array}{l}\frac{\lambda}{2} \\
\frac{2}{2} \\
\text { ஸ } \\
\text { ல }\end{array}$ \\
\hline \multirow[t]{2}{*}{ Indoor } & $\begin{array}{l}\text { Spirulin } \\
\text { a sp. } \\
\text { Scened } \\
\text { esmus } \\
\text { obliquus }\end{array}$ & - & 30 & $\begin{array}{c}\text { Determined } \\
\text { by a digital } \\
\text { pH-meter }\end{array}$ & $\begin{array}{c}\text { Agitation } \\
\text { and } \\
\text { aeration } \\
\text { using air } \\
\text { from a } \\
\text { compres } \\
\text { sor and } \\
\text { a } \\
\text { sintered } \\
\text { sparger }\end{array}$ & $\begin{array}{c}\text { A 12h } \\
\text { dark/light } \\
\text { photo } \\
\text { period } \\
\text { with } \\
3200 \text { lux } \\
\text { of } \\
\text { illuminati } \\
\text { on } \\
\text { provided } \\
\text { by } 40 \mathrm{~W} \\
\text { daylight } \\
\text { type } \\
\text { fluoresce } \\
\text { nt lamp }\end{array}$ & $\begin{array}{l}\mathrm{CO}_{2} \\
\text { added to } \\
\text { the air at } \\
\text { a rate of } \\
0.3 \mathrm{wm} \\
\text { for } 15 \\
\text { min } \\
\text { every } 2 \mathrm{~h} \\
\text { during } \\
\text { the } 12 \mathrm{~h} \\
\text { light } \\
\text { period }\end{array}$ \\
\hline & $\begin{array}{c}\text { Chicrell } \\
\text { asorckin } \\
\text { iana }\end{array}$ & 58 & \multicolumn{2}{|c|}{$\begin{array}{c}\text { Controlle } \\
\text { d by } \\
\text { sprinking } \\
\text { the } \\
\text { reactor } \\
\text { surface } \\
\text { with tap } \\
\text { water }\end{array}$} & & $\begin{array}{l}\text { Natural } \\
\text { illuminati } \\
\text { on by } \\
\text { solar } \\
\text { light } \\
\text { energy }\end{array}$ & $\begin{array}{l}\mathrm{CO}_{2} \\
\text { added to } \\
\text { the air a } \\
\text { rate of } \\
0.25 \mathrm{wm}\end{array}$ \\
\hline $\begin{array}{l}\text { Outdoor: } \\
\text { consistin } \\
\text { g of } 4 \mathrm{~m} \\
\text { tall airlift } \\
\text { section } \\
\text { with a } \\
\text { degassed } \\
\text { zone }\end{array}$ & $\begin{array}{c}p . \\
\text { tricornut } \\
\text { um } \\
\end{array}$ & 200 & & & $\begin{array}{c}\text { Airlift } \\
\text { device }\end{array}$ & $\begin{array}{c}\text { Solar } \\
\text { illuminati } \\
\text { on }\end{array}$ & \\
\hline $\begin{array}{l}\text { Semi- } \\
\text { continuou } \\
\text { s }\end{array}$ & Chlorlla & & $26 \pm 1$ & $\begin{array}{c}\text { Directly } \\
\text { determined } \\
\text { by an } \\
\text { ISFET pH - } \\
\text { meter } \\
\text { KS723 }\end{array}$ & & $\begin{array}{l}\text { Continuous } \\
\text { cool white } \\
\text { fluorescent } \\
\text { illumination at } \\
\text { the intensity } \\
300 \text { umol } \\
\mathrm{m}^{-2} \mathrm{~s}^{-1} \\
\text { measured at } \\
\text { the } \\
\text { photobioreakt } \\
\text { r using a Bapai } \\
\text { Quantum } \\
\text { Meter }\end{array}$ & $\begin{array}{l}\text { Air of } \\
\text { different } \\
\mathrm{CO}_{2} \\
\text { concentrat } \\
\text { on produc } \\
\text { nixing air } \\
\text { and pure } \\
\mathrm{CO}_{2} \text { at rate } \\
\text { of } 0.25 \mathrm{wm}\end{array}$ \\
\hline $\begin{array}{l}\text { Channel } \\
\text { chambters inter } \\
\text { connected by } \\
\text { means of } \\
\text { horizontal } \\
\text { baffles attached } \\
\text { alternately to } \\
\text { the front and } \\
\text { the back of the } \\
\text { larger flat faces } \\
\text { of the reactor }\end{array}$ & d & 3 & $\begin{array}{c}\text { Controlle } \\
d \text { by } \\
\text { circulatin } \\
\mathrm{g} \text { cooling } \\
\text { water } \\
\text { through } \\
a \\
\text { transpar } \\
\text { ent } \\
\text { jacket } \\
\text { located } \\
\text { at the } \\
\text { front of } \\
\text { the } \\
\text { reactor }\end{array}$ & $\begin{array}{c}6.8 \pm 1 \\
\text { measured } \\
\text { by a sensor } \\
\text { placed in } \\
\text { the upper } \\
\text { part of the } \\
\text { reactor and } \\
\text { controlled } \\
\text { by injecting } \\
\mathrm{Co}_{2} \text { by } \\
\text { demand }\end{array}$ & $\begin{array}{l}\text { By a } \\
\text { peristaltic } \\
\text { pump }\end{array}$ & $\begin{array}{l}\text { Illuminati } \\
\text { on from } \\
\text { the both } \\
\text { side of } \\
\text { the } \\
\text { tubes } \\
\text { with } 4 \\
\text { OsramFI } \\
\text { uora } \\
\text { lamps at } \\
\text { the } \\
\text { intensity } \\
\text { of } 120 \\
\mu \mathrm{Em}^{-2} \mathrm{~s}^{-1}\end{array}$ & $\begin{array}{c}\mathrm{CO}_{2} \\
\text { added to } \\
\text { the air a } \\
\text { rate of } \\
0.45 \mathrm{wm}\end{array}$ \\
\hline
\end{tabular}

